\title{
Electrochemical acetylcholinesterase biosensor for detection of cholinesterase inhibitors: study with eserine
}

\author{
Nina Lokarl, Veno Kononenko², Damjana Drobne ${ }^{2}$, Danilo Vrtačnik ${ }^{1}$
}

${ }^{1}$ University of Ljubljana, Faculty of Electrical Engineering, Laboratory of Microsensor Structures and Electronics, Ljubljana, Slovenia

${ }^{2}$ University of Ljubljana, Biotechnical Faculty, Department of Biology, Ljubljana, Slovenia

\begin{abstract}
Cholinesterase inhibitors are widely used as pesticides, as chemical warfare agents and as drugs to treat symptoms of Alzheimer's disease. Therefore, it is a high need to develop methods for their detection which are fast, sensitive, and reliable. This paper reports a preliminary work in the development of an electrochemical biosensor based on acetylcholinesterase (AChE) which is constructed by immobilization layers - cysteamine/glutaraldehyde/AChE on thin layer gold electrode for detection of cholinesterase inhibitors. Eserine (physostigmine) was used as a test inhibitor. The enzyme immobilization efficacy was evaluated by measuring activity of immobilized enzyme via Ellman's method. The enzyme activity of the initial reduction of 33\% in five days remained after that stable for at least one week. Chronoamperometric response to substrate acetylthiocholine chloride (ATCl) was assumed to follow Michaelis-Menten kinetics. After exposure biosensor to $25 \mu \mathrm{M}$ eserine for $10 \mathrm{~min}, 70 \%$ inhibition of enzyme was detected. Reactivation factor of inhibited AChE was determined as $0.016 \mathrm{~min}^{-1}$.
\end{abstract}

\section{Elektrokemijski acetilholinesterazni biosenzor za detekcijo holinesteraznih inhibitorjev: raziskava z eserinom}

\begin{abstract}
Izvleček: Holinesterazni inhibitorji se pogosto uporabljajo kot pesticidi, kot kemična bojna sredstva ali kot zdravila za zdravljenje simptomov Alzheimerjeve bolezni, zaradi česar je razvoj hitrih, občutljivih in zanesljivih metod za njihovo zaznavanje izrednega pomena. Članek podaja rezultate začetnih raziskav v razvoju elektrokemijskega biosenzorja za detekcijo inhibitorjev acetilholinesteraze (AChE). Biosenzor je zgrajen na steklenem substratu, na katerem je strukturirana tankoplastna zlata elektroda. Na njej so imobilizirani cisteamin/glutaraldehid/AChE. Kot testni inhibitor je uporabljen eserin (fizostigmin). Učinkovitost imobilizacije encima smo spremljali z merjenjem aktivnosti imobiliziranega encima z Ellmanovo metodo. Po petih dneh od izdelave biosenzorja se je aktivnost encima stabilizirala. Kronoamperometrični odziv na substrat acetiltioholin klorid (ATCl) je predpostavljeno sledil kinetiki Michaelisa in Mentenove. Po 10 minutni izpostavljenosti biosenzorja $25 \mu \mathrm{M}$ eserinu smo detektirali 70\% inhibicijo encima. Reaktivacijski faktor inhibiranega AChE je bil $0.016 \mathrm{~min}^{-1}$
\end{abstract}

Ključne besede: elektrokemijski biosenzor; acetilholinesteraza; eserin; Ellmanova metoda; kronoamperometrija; ciklična voltametrija

*Corresponding Author's e-mail: nina.lokar@fe.uni-lj.si

\section{Introduction}

In 1962, Clark and Lyons proposed the initial concept of glucose enzyme electrodes which led to a powerful analytical instrument for the detection of glucose in samples from patients with diabetes. This resulted in popularization of biosensors [1, 2]. In comparison with the conventional analytical techniques (such as chromatography and mass spectrometry), biosensors are typically easy to use, suitable for in situ measurement, and low cost [3]. Biosensors are remarkably diverse, 
comprising a wide range of combinations of biorecognition and transduction elements [4, 5]. Enzymes are the most often used bio-recognition elements, whereas the most widely applied biosensors are based on electrochemical transduction method [6].

Enzyme-based biosensors are implemented in direct or indirect form [5]. One example of indirect form option is cholinesterase (ChE) biosensors which are based on enzyme inhibition $[7,8]$. They are useful tools for detection of ChE inhibitors. The most widespread applications of such biosensors are detection of pesticides (organophosphates and carbamates) and warfare nerve agents (sarin) [6]. ChE inhibitors are also recognized as prevailing choice (galantamine, rivastigmine, donepezil) in the treating of Alzheimer's disease symptoms [9]. For these applications, the inhibitors detection and analysis are of great importance. Eserine has been used by many researchers as a reference standard in the evaluation of new ChE inhibitors [10]. Eserine can be found naturally in the Calabar bean. Eserine binds at both the anionic and esteric sites of acetylcholinesterase (AChE), forming a drug-enzyme complex. The mechanism is not completely reversible [11].

This paper reports construction of an AChE biosensor based on immobilization layers of cysteamine, glutaraldehyde, and $\mathrm{AChE}$, which are chemically bound to the thin gold electrode layer. Cyclic voltammetry (CV) and chronoamperometry (CA) were applied to demonstrate the fasibility of fabricated biosensor structure for the detection of one well-known and important neurotransmitter inhibitor eserine.

\section{Materials and methods}

\subsection{Chemicals}

Following compounds were purchased from Merck (Germany): $95-98 \% \mathrm{H}_{2} \mathrm{SO}_{4^{\prime}} 30 \% \mathrm{H}_{2} \mathrm{O}_{2}, 100$ mM cysteamine, glutaraldehyde $5 \%(\mathrm{v} / \mathrm{v})$, AChE from electric eel (50 U/mL), $100 \mathrm{mM} \mathrm{K-P}$ buffer solution with $\mathrm{pH}=8.0$ (47 mL $1 \mathrm{M} \mathrm{K}_{2} \mathrm{HPO}_{4}+3 \mathrm{~mL} 1 \mathrm{M} \mathrm{KH}_{2} \mathrm{PO}_{4}+450 \mathrm{~mL}$ miliQ water), $5 \mathrm{mM}$ (if not specified differently) substrate acetylthiocholine chloride solution (ATCl), and $10 \mathrm{mM}$ eserine. $0.1 \mathrm{M} \mathrm{KCl}$ containing $2 \mathrm{mM}$ ferri/ferro-cyanide were prepared and purchased from Merck and Fluka (Belgium), respectively.

\subsection{Instruments}

Spectrophotometry was carried out by microplate reader Cytation 3 from BioTek (Germany).
CV and CA measurements were carried out using potentiostat EmStat3+ Blue equipped with PSTrace 5.3 software from PalmSens BV (The Netherlands). Miniature $\mathrm{Ag} / \mathrm{AgCl}, 3 \mathrm{M} \mathrm{KCl}$ reference electrode, model ET073 was from eDAQ Pty Ltd (Australia).

\subsection{Biosensor structure}

Electrodes. Replaceable chip, containing an array of 6 thin layer gold working electrodes (Figure1a) was manufactured. Gold electrodes were applied on glass substrate using microfabrication processes - sputtering of $\mathrm{Cr} / \mathrm{Au}$ with thicknesses $30 \mathrm{~nm} / 120 \mathrm{~nm}$, photolithography patterning and wet etching. The diameter of the working electrodes was $0.3 \mathrm{~cm}$, resulting in an apparent geometric area of $0.07 \mathrm{~cm}^{2}$. As counter (or auxiliary) electrode, platinum wire was used, and it was wrapped around the external reference electrode (Figure $1 \mathrm{~b}$ ). All three electrodes were installed in an originally designed electrochemical cell with reservoir volume of $5 \mathrm{~mL}$ (Figure 1c). Chip with working electrodes in electrochemical cell was connected to potentiostat (Figure 1d) with spring tips.

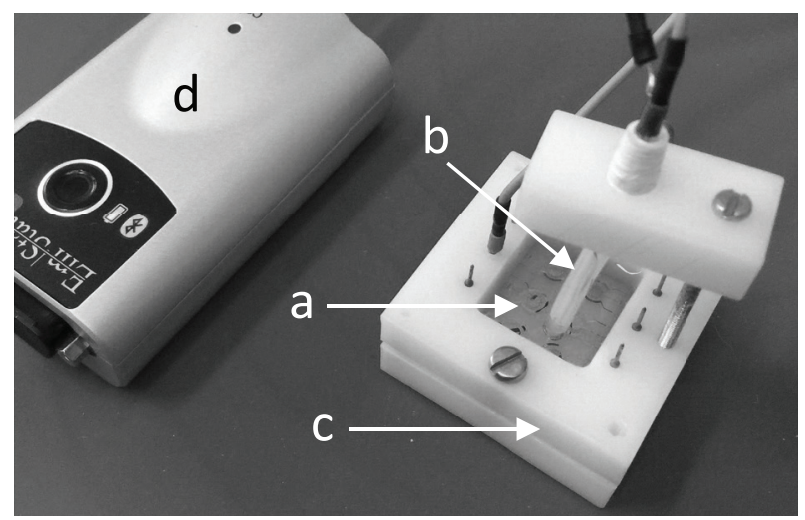

Figure 1: Experimental setup of biosensor.

AChE immobilization. Gold electrode chip was first cleaned with piranha solution $\left(\mathrm{H}_{2} \mathrm{SO}_{4}: \mathrm{H}_{2} \mathrm{O}_{2}\right.$ in volume ratio 3:1), for 10 minutes. Thereafter, the electrode chip was well rinsed with ultrapure water and imme-

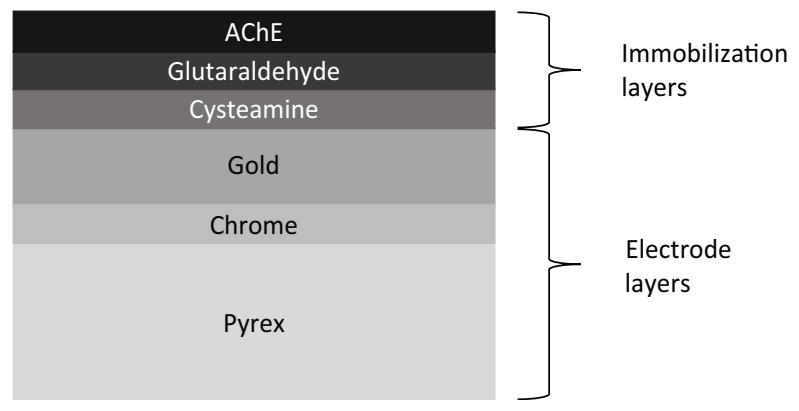

Figure 2: AChE immobilized gold electrode. 
diately immersed in cysteamine, glutaraldehyde aqueous solution and in AChE solution as described in [12]. Schematic description of resulting sample structure is shown in Figure 2.

\subsection{Measurement procedure}

AChE activity measurement. AChE hydrolyses ATCI to acetate and thiocholine chloride ( $\mathrm{TChCl}$ ) which can be further measured spectrophotometrically [13]. Standard spectrophotometric Ellman colorimetric assay [14] was used to check the efficacy of the enzyme immobilization procedure on the gold surface. Test gold plated glass with $0.2 \mathrm{~cm}^{2}$ had AChE immobilized as described previously. The absorbance of yellow product 5-thio2-nitrobenzoate (TNB) was measured after reaction time of 10 minutes and the product quantity was evaluated using the Lambert-Beer law as Eq. 1 [15]:

Product quantity $=\frac{A V}{\varepsilon l}$

where $A$ is absorbance at $405 \mathrm{~nm}, V$ is volume of the sample (products TChCl, Ellman's reagent, K-P buffer), $\varepsilon$ known molar extinction coefficient of TNB $(\varepsilon=$ $14,150 \mathrm{M}^{-1} \mathrm{~cm}^{-1}[16]$ and / is the beam length in the sample, respectively. In our case parameters were: $V=250$ $\mu \mathrm{L}, I=0.75 \mathrm{~cm}$.

CV and CA techniques [17] were applied to measure enzyme activity on immobilized gold electrode chip. In the case of measurement by $\mathrm{CV}$, the input voltage

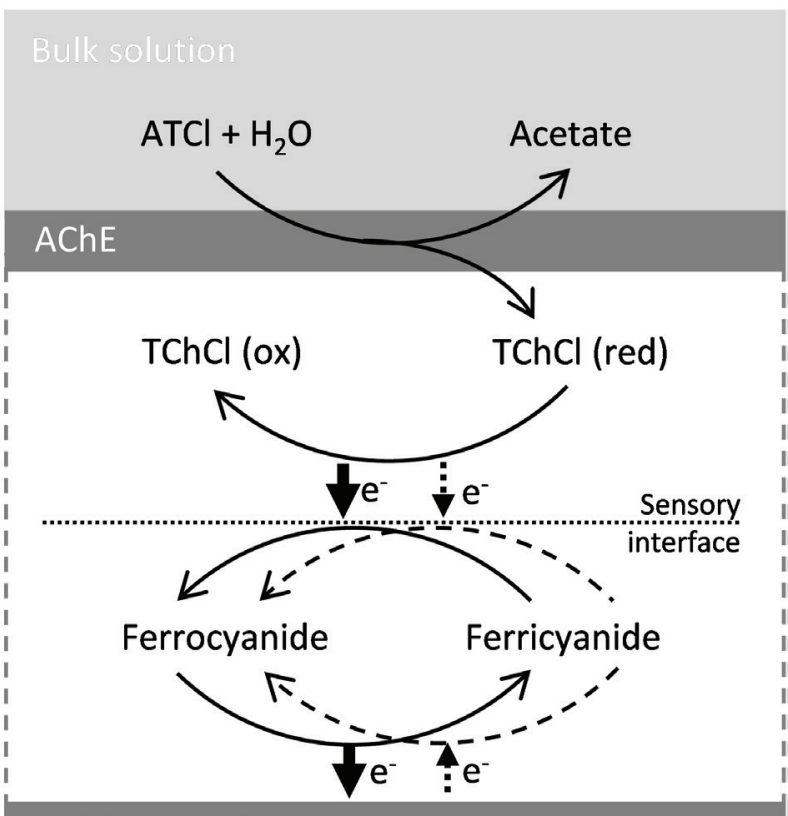

Gold electrode

Figure 3: Sequence of reactions occurring at AChE biosensor. was scanned from $-0.1 \mathrm{~V}$ to $+0.6 \mathrm{~V}$, with potential step of $0.01 \mathrm{~V}$ and scan rate of $0.06 \mathrm{~V} / \mathrm{s}$. CA measurement was carried out at DC potential of $0.4 \mathrm{~V}$. Measurements, if not specified differently, were performed 10 minutes after exposure substrate ATCl to AChE enzyme. Substrate was dissolved in K-P buffer and solution of ferricyanide with $\mathrm{KCl}$. Sequence of reactions occurring at an AChE biosensor is shown schematically in Figure 3. The result of the ATCl hydrolysis is the electrochemically active $\mathrm{TChCl}$, which exchanges an electron with an electrochemical mediator ferricyanide when passing from reduction to oxidation state. Mediator transfers the electron to the electrode via redox reactions. Oxidation and reduction process on cyclic voltammogram are referred to solid and dashed lines in Figure 3, respectively $[18,19]$. Electrons on the electrode are detected by external electrical circuit (potentiostat).

AChE inhibition measurement. AChE biosensor is based on enzymatic inhibition mechanism. Eserine as analyte inhibits the normal enzyme function. The enzyme inhibition is therefore determined by the difference in measured electric currents in the absence $\left(i_{0}\right)$ and presence (i) of eserine. The inhibition is calculated as Eq. 2 [20]:

Inhibition $=\left(i_{0}-i_{i}\right) / i_{0}$

Measuring protocol of AChE inhibition was performed in three steps. The biosensor was immersed in the substrate ATCl solution and solution of ferricyanide with $\mathrm{KCl}$, for $10 \mathrm{~min}$ and the signal $i_{0}$ was measured (step 1). Then, the AChE biosensor was rinsed three-times with the K-P buffer solution (step 2) and immersed in a new substrate and ferricyanide solution with eserine addition for reaction and incubation time of $10 \mathrm{~min}$, then residual activity $i$, was measured (step 3 ).

\section{Results and discussion}

Activity of the immobilized enzyme was evaluated spectrophotometrically by measuring the quantity of produced thiocholine chloride product. The activity was monitored in time period of 12 days (Figure 4).

From Figure 4 it can be seen that after 33\% initial decrease of enzyme activity in five days, the activity remained steady for at least one week. The reason for large initial loss of activity can be attributed to stabilization of biostructure or incomplete covalent binding of the enzyme, surface defects and impurity of enzyme.

After confirming immobilized enzyme activity by Ellman's method, AChE biosensor performance was investigated by $C V$ and $C A$ measurements on biosensor 
electrode structure. Figure 5 shows CV response obtained in absence and in presence of ATCl.

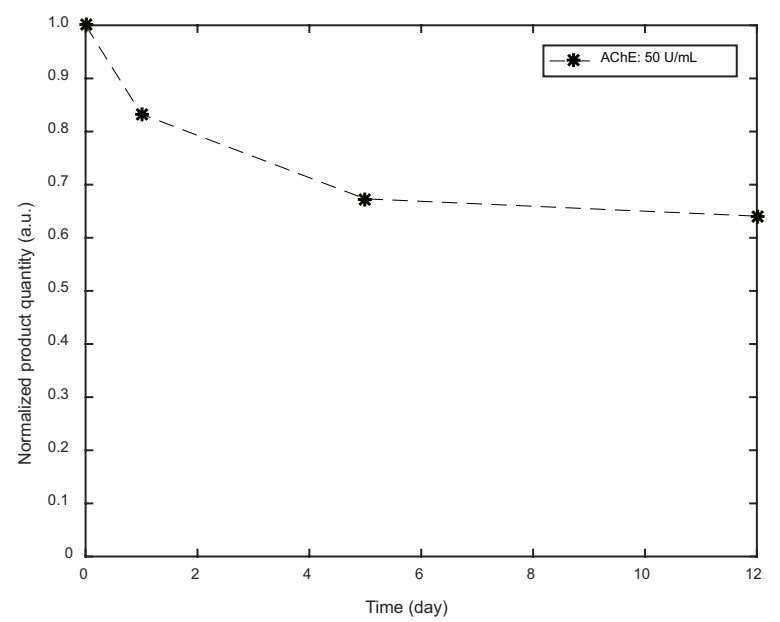

Figure 4: Spectrophotometrical measurement of time dependent AChE activity.

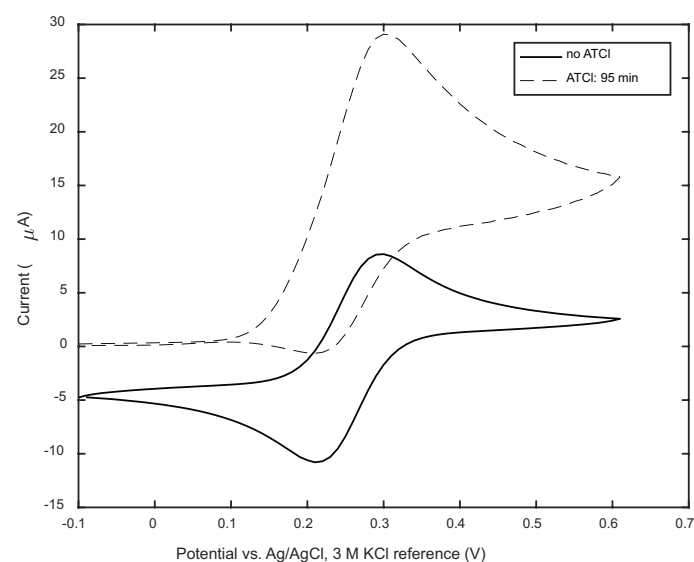

Figure 5: Cyclic voltammogram obtained in absence (solid line) and in presence of substrate ATCI (discontinuous line) in the presence of redox couple ferri/ferro-cyanide. The reaction with substrate refer to ATCI hydrolysis, catalysed by the enzyme AChE.

Addition of ATCl causes an increase in concentration of $\mathrm{TChCl}$ and consequently of the ferrocyanide, resulting in an increase of the anodic peak current. On the contrary, the cathodic peak current is proportional to the amount of ferricyanide that decreases after the addition of ATCl. This can be seen in Figure 5, where anodic peak current $I_{p a}$ increases and cathodic peak current $I_{p c}$ decreases with time of $\mathrm{TChCl}$ present. Therefore, we can determine a ratio $I_{p d} I_{p c}$. The ratio of the peak currents is equal to one for reversible system of ferro/ferri-cyanide, shown by solid line in Figure 5. Larger peak current difference is obtained for reaction with ATCl, shown by dashed line in Figure 5, for the reaction time of $95 \mathrm{~min}$. The corresponding ratio of the peak currents was therefore determined as 3.1. This confirms higher rate of oxidation and consequently concentration of produced $\mathrm{TChCl}$.
Figure 6 shows measured current by CA technique and fitted result (solid line) versus ATCI concentration.

(a)

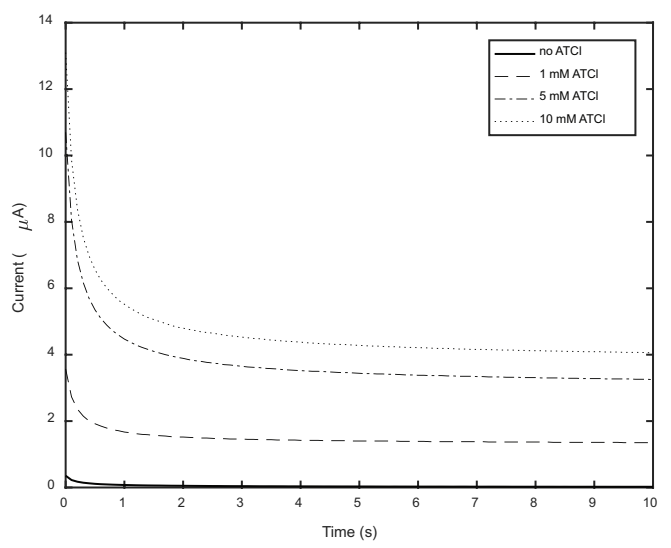

(b)

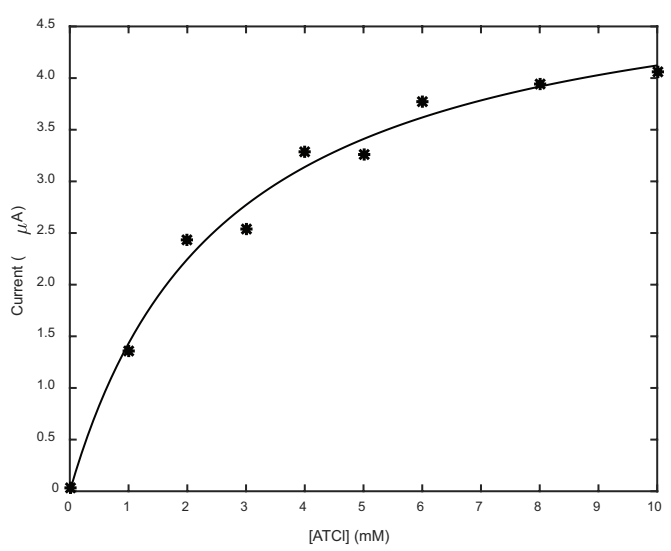

Figure 6: Selected chronoamperometric curves (a) from which (at $10 \mathrm{~s}$ ) calibration plot of ATCl using the AChE biosensor is constructed (b).

Relation between electrical current and concentration of substrate ATCl was assumed to follow MichaelisMenten kinetics (Eq. 3) [21], being aware that many other factors can affect the results [22]:

$V_{0}=\frac{V_{\max }[S]}{K_{M}+[S]}$

where $V_{0}$ is initial velocity, $V_{\text {max }}$ is maximum velocity, $[S]$ is substrate concentration, and $K_{M}$ is Michaelis constant. According to the curve fit of measured points in Figure 6 (solid line), the calculated apparent Michaelis constant $K_{M}^{a p p}=2.6 \pm 0.9 \mathrm{mM}$ was determined.

Finally, after determining production of $\mathrm{TChCl}$ by $\mathrm{AChE}$ biosensor, AChE inhibition was chronoamperometricaly detected by using well-established commercially available AChE inhibitor eserine. The inhibition of $A C h E$ was determined by measuring the decrease of the $C A$ signal, which is consequence of eserine addition to the ATCl substrate solution. Result of inhibition for $25 \mu \mathrm{M}$ of concentration of eserine is presented in Figure 7. 


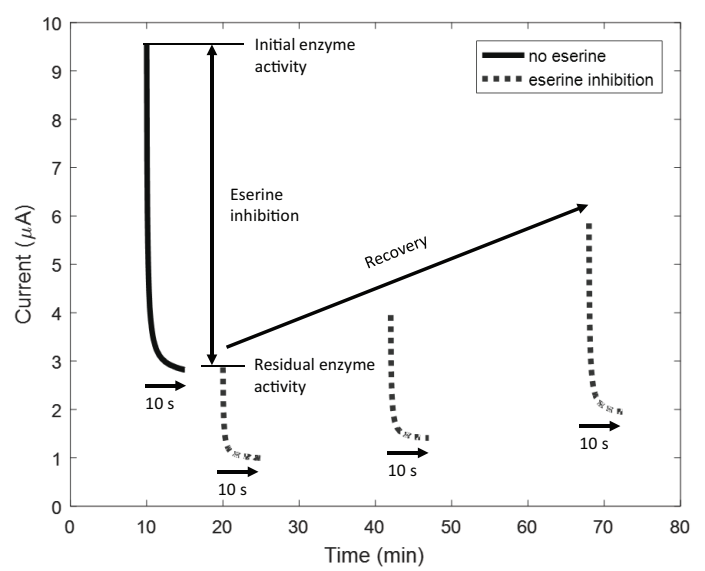

Figure 7: Study of AChE inhibition by eserine.

Both, initial enzyme inhibition in value of $70 \%$ and recovery of AChE activity are presented in Figure 7. After 10 minutes of inhibition by eserine, samples were repeatedly rinsed and re-measured, noting the significant recovery of the signal. Note that each measurement, presented in Figure 7, lasted only $10 \mathrm{~s}$, while time on $\mathrm{x}$-axis shows the total time of experiment duration. It can be seen that recovery of AChE activity increases almost linearly with time (20 to $68 \mathrm{~min}$ ) when system was not exposed to eserine, recovering to $59 \%$ and $39 \%$ of inhibition at 42 and 68 min, respectively.

An important kinetic parameter of inhibited AChE is the reactivation factor $K_{\text {react }}$. By applying Perola's equation (Eq. 4), the reactivation factor $K_{\text {react }}$ was calculated from the inclination of the linear plot obtained by monitoring the inhibition as a function of time [23]:

$\ln \left(\frac{\text { Inhibition }_{t}}{\text { Inhibition }_{0}}\right)=-K_{\text {react }} t$

where Inhibition ${ }_{0}$ is the first measured current after inhibitor addition, which corresponded to $t=0$ of the decarbamoylation phase, and Inhibition ${ }_{t}$ is the inhibition determined as a function of time during the enzyme activity recovery phase. $K_{\text {react }}$ of $0.016 \mathrm{~min}^{-1}$ was determined, and it is in good agreement with the literature data [24].

\section{Conclusions}

The AChE electrochemical biosensor is presented. It is successfully applied for detection of eserine as an example of choline inhibitor in water.

Spectrophotometric measurements have shown that five days after AChE immobilisation on gold surface activity of an enzyme decreased for $33 \%$ and then remained stable an extended period of time.

Biosensor was evaluated via $\mathrm{CV}$ and $\mathrm{CA}$ measurements. $\mathrm{CV}$ measurement of enzyme activity resulted in asymmetric cyclic voltammogram, i.e. increase of anodic peak current and decrease of cathodic peak current (ratio 3:1). This confirms higher rate of oxidation and consequently concentration of produced $\mathrm{TChCl}$. Moreover, relation between electrical current and concentration of substrate ATCl up to $10 \mathrm{mM}$ were assumed to follow Michaelis Menten kinetics. Apparent Michaelis constant was determined as $2.6 \pm 0.9 \mathrm{mM}$.

Our results have shown that $25 \mu \mathrm{M}$ eserine inhibits the activity of AChE for $70 \%$. Reactivation factor of $0.016 \mathrm{~min}^{-1}$ was determined, showing reversibility of AChE inhibition by eserine.

Presented work is to be further extended to determine biosensor sensitivity, reliability and concentration dependent inhibition of eserine and other AChE inhibitors.

\section{Acknowledgments}

The authors acknowledge the financial support from the Slovenian Research Agency (research core funding No. P2-0244 and contract No. 1000-18-0510 - with Faculty of Electrical Engineering). Work was partly financed by Mediterranean Institute for Monitoring in the frame of collaboration with Biotechnical Faculty.

\section{References}

1. A. P. F. Turner, 'Biosensors: sense and sensibility', Chemical Society Reviews, vol. 42, no. 8, p. 3184, 2013. https://doi.org/10.1039/c3cs35528d

2. L. C. Clark and C. Lyons, 'Electrode systems for continuous monitoring in cardiovascular surgery', Annals of the New York Academy of Sciences, vol. 102, no. 1, pp. 29-45, Oct. 1962. https://doi. org/0.1111/j.1749-6632.1962.tb13623.x

3. A. Amine, S. Cinti, F. Arduini, D. Moscone, and G. Palleschi, 'How to extend range linearity in enzyme inhibition-based biosensing assays', Talanta, vol. 189, pp. 365-369, Nov. 2018. https:// doi.org/10.1016/j.talanta.2018.06.087

4. D. R. Thévenot, K. Toth, R. A. Durst, and G. S. Wilson, 'Electrochemical biosensors: recommended definitions and classification1', Biosensors and Bioelectronics, vol. 16, no. 1-2, pp. 121-131, 2001. https://doi.org/10.1081/AL-100103209

5. D. G. Rackus, M. H. Shamsi, and A. R. Wheeler, 'Electrochemistry, biosensors and microfluidics: a 
convergence of fields', Chemical Society Reviews, vol. 44, no. 15, pp. 5320-5340, 2015. https://doi. org/10.1039/C4CS00369A

6. Š. Štěpánková and K. Vorčáková, 'Cholinesterasebased biosensors', Journal of Enzyme Inhibition and Medicinal Chemistry, vol. 31, no. sup3, pp. 180-193, Nov. 2016. https://doi.org/10.1080/147 $\underline{56366.2016 .1204609}$

7. L. Matějovský and V. Pitschmann, 'New Carrier Made from Glass Nanofibres for the Colorimetric Biosensor of Cholinesterase Inhibitors', Biosensors, vol. 8, no. 2, p. 51, May 2018. https://doi. org/10.3390/bios8020051

8. V. Dhull, A. Gahlaut, N. Dilbaghi, and V. Hooda, 'Acetylcholinesterase Biosensors for Electrochemical Detection of Organophosphorus Compounds: A Review', Biochemistry Research International, vol. 2013, pp. 1-18, 2013. https:// doi.org/10.1155/2013/731501

9. W. Hussein et al., 'Synthesis and Biological Evaluation of New Cholinesterase Inhibitors for Alzheimer's Disease', Molecules, vol. 23, no. 8, p. 2033, Aug. 2018. https://doi.org/10.3390/ molecules23082033

10. T. J. Petcher and P. Pauling, 'Cholinesterase Inhibitors: Structure of Eserine', Nature, vol. 241, p. 277, Jan. 1973. https://doi.org/10.1038/241277a0

11. L. -G. Zamfir, L. Rotariu, and C. Bala, 'Acetylcholinesterase biosensor for carbamate drugs based on tetrathiafulvalene-tetracyanoquinodimethane/ionic liquid conductive gels', Biosensors and Bioelectronics, vol. 46, pp. 61-67, Aug. 2013. https://doi.org/10.1016/j.bios.2013.02.018

12. F. Arduini, S. Guidone, A. Amine, G. Palleschi, and D. Moscone, 'Acetylcholinesterase biosensor based on self-assembled monolayer-modified goldscreen printed electrodes for organophosphorus insecticide detection', Sensors and Actuators B: Chemical, vol. 179, pp. 201-208, Mar. 2013. https://doi.org/10.1016/j.snb.2012.10.016

13. F. Arduini, A. Amine, D. Moscone, and G. Palleschi, 'Biosensors based on cholinesterase inhibition for insecticides, nerve agents and aflatoxin B1 detection (review)', Microchimica Acta, vol. 170, no. 3-4, pp. 193-214, Sep. 2010. https://doi. org $/ 10.1007 / \mathrm{s} 00604-010-0317-1$

14. G. L. Ellman, K. D. Courtney, V. Andres, and R. $M$. Featherstone, 'A new and rapid colorimetric determination of acetylcholinesterase activity', Biochemical Pharmacology, vol. 7, no. 2, pp. 88-95, Jul. 1961. https://doi.org/10.1016/00062952(61)90145-9

15. G. L. Ellman, 'Tissue sulfhydryl groups', Archives of Biochemistry and Biophysics, vol. 82, no. 1, pp. 70-77, May 1959. https://doi.org/10.1016/00039861(59)90090-6
16. M. Pohanka, M. Hrabinova, K. Kuca, and J. -P. Simonato,'Assessment of Acetylcholinesterase Activity Using Indoxylacetate and Comparison with the Standard Ellman's Method', International Journal of Molecular Sciences, vol. 12, no. 4, pp. 2631-2640, Apr. 2011. https://doi.org/10.3390/ijms12042631

17. N. Elgrishi, K. J. Rountree, B. D. McCarthy, E. S. Rountree, T. T. Eisenhart, and J. L. Dempsey, 'A Practical Beginner's Guide to Cyclic Voltammetry', Journal of Chemical Education, vol. 95, no. 2, pp. 197-206, Feb. 2018. https://doi.org/10.1021/acs. jchemed.7b00361

18. P. Abad-Valle, H. Y. Aboul-Enein, J. Adrian, and S. Alegret, 'Contributors to Volume 49', vol. 49, p. 1308.

19. Faculty of Chemical Technology, University of Pardubice, Studentska 95, Pardubice, Czech Republic and A. Kostelnik, 'Electrochemical Determination of Activity of Acetylcholinesterase Immobilized on Magnetic Particles', International Journal of Electrochemical Science, pp. 4840-4849, Jun. 2016. https://doi.org/10.20964/2016.06.39

20. S. Kurbanoglu, C. C. Mayorga-Martinez, M. Medina-Sánchez, L. Rivas, S. A. Ozkan, and A. Merkoçi, 'Antithyroid drug detection using an enzyme cascade blocking in a nanoparticle-based lab-on-achip system', Biosensors and Bioelectronics, vol. 67, pp. 670-676, May 2015. https://doi.org/10.1016/j. bios.2014.10.014

21. R. F. Boyer, Concepts in Biochemistry, 3 edition. Hoboken, NJ: Wiley, 2005.

22. M.-P. Bucur, B. Bucur, and G.-L. Radu, 'Critical Evaluation of Acetylthiocholine lodide and Acetylthiocholine Chloride as Substrates for Amperometric Biosensors Based on Acetylcholinesterase', Sensors (Basel), vol. 13, no. 2, pp. 1603-1613, Jan. 2013. https://doi.org/10.3390/s130201603

23. M. Vandeput et al., 'Flow-through enzyme immobilized amperometric detector for the rapid screening of acetylcholinesterase inhibitors by flow injection analysis', Journal of Pharmaceutical and Biomedical Analysis, vol. 102, pp. 267-275, Jan. 2015. https://doi.org/10.1016/j.jpba.2014.09.012

24. E. Perola, L. Cellai, D. Lamba, L. Filocamo, and M. Brufani, 'Long chain analogs of physostigmine as potential drugs for Alzheimer's disease: new insights into the mechanism of action in the inhibition of acetylcholinesterase', Biochimica et Biophysica Acta (BBA) - Protein Structure and Molecular Enzymology, vol. 1343, no. 1, pp. 41-50, Nov. 1997. https://doi. org10.1016/S0167-4838(97)00133-7

Arrived: 31.08. 2018

Accepted: 24. 10. 2018 